\title{
RESEARChArTicle
}

\section{Genetic variability, heritability and genetic advance of yield and quality traits in linseed (Linum usitatissimum L.)}

\author{
SHIPRA SHALINI, SOHAN RAM, SHANTI BHUSHAN AND EKHLAQUE AHMAD
}

\section{SUMMARY}

The present studies were carried out with a set of eight varieties of linseed and their twenty eight $\mathrm{F}_{1}$ 's obtained through diallel crossing excluding reciprocals. The eight parents and their $28 \mathrm{~F}_{1} \mathrm{~s}$ were grown in a randomised block design during Rabi season of 2012 and studied for fifteen quantitative and qualitative characters. The analysis of variance showed highly significant differences among the genotypes for all the characters studied except days to maturity in $\mathrm{F}_{1} \mathrm{~s}$. The genetic co-efficient of variance was high in number of capsules per plant, linolenic acid content in $\mathrm{F}_{1} \mathrm{~s}$. The highest value of heritability was observed in linoleic acid content among parents whereas among crosses it was the highest in case of linolenic acid. Highest genetic advance was exhibited by number of capsules per plant in case of both parents and crosses. Genetic advance expressed as per cent of mean was the highest in steric acid per cent for parent and seed yield per plant for crosses in $\mathrm{F}_{1} \mathrm{~s}$. The traits with high heritability and high genetic advance may be subjected to mass or progeny or family selection or any selection scheme, aimed at exploiting additive (fixable) genetic variance, a widely adapted genotype can be developed, possessing good quality and high productivity.

Key Words : Linseed, Genetic variability, Heritability

How to cite this article : Shalini, Shipra, Ram, Sohan, Bhushan, Shanti and Ahmad, Ekhlaque (2016). Genetic variability, heritability and genetic advance of yield and quality traits in linseed (Linum usitatissimum L.). Internat. J. Plant Sci., 11 (2): 270-274, DOI: 10.15740/HAS/IJPS/11.2/270-274.

Article chronicle : Received : 08.02.2016; Revised : 01.05.2016; Accepted : 08.06.2016

\section{MEMBERS OF THE RESEARCH FORUM}

Author to be contacted :

SOHAN RAM, Department of Plant Breeding and Genetics, Birsa Agricultural University, Kanke, RANCHI (JHARKHAND) INDIA

Email: sohanrambau@ rediffmail.com

Address of the Co-authors:

SHIPRA SHALINI AND SHANTI BHUSHAN, Department of Plant Breeding and Genetics, Birsa Agricultural University, Kanke, RANCHI (JHARKHAND) INDIA

EKHLAQUE AHMAD, Zonal Research Station (B.A.U.), Chianki, RANCHI (JHARKHAND) INDIA 